\title{
Overexpressed Long Noncoding RNA TUGI Affects the Cell Cycle, Proliferation, and Apoptosis of Pancreatic Cancer Partly Through Suppressing RND3 and MT2A [Retraction]
}

\author{
Hui B, Xu Y, Zhao B, et al. Onco Targets Ther. \\ 2019;12:1043-1057.
}

The Editor and Publisher of OncoTargets and Therapy wish to retract the published article. Concerns were raised over alleged image duplication between Figures $2 \mathrm{~F}$ and $6 \mathrm{E}$. Specifically:

- Figure 2F, panel AsPC-1 Empty vector appears to have been duplicated with Figure 6E, panel BxPC-3 si-NC.

The author responded to our queries but were unable to provide a satisfactory explanation for the alleged duplica- tion and could not provide the original data for the study. The Editor requested for the article to be retracted and the authors agreed with this decision. The authors wish to apologise for this error.

Our decision-making was informed by our policy on publishing ethics and integrity and the COPE guidelines on retraction.

The retracted article will remain online to maintain the scholarly record, but it will be digitally watermarked on each page as "Retracted".

\section{Publish your work in this journal}

OncoTargets and Therapy is an international, peer-reviewed, open access journal focusing on the pathological basis of all cancers, potential targets for therapy and treatment protocols employed to improve the management of cancer patients. The journal also focuses on the impact of management programs and new therapeutic agents and protocols on patient perspectives such as quality of life, adherence and satisfaction. The manuscript management system is completely online and includes a very quick and fair peer-review system, which is all easy to use. Visit http://www.dovepress.com/ testimonials.php to read real quotes from published authors. 